\title{
腹腔鏡下摘出術を行った非交通性副角子宮の2例
}

兵庫県立尼崎総合医療センター

\author{
廣瀬雅哉、佐藤＼cjkstart浩、池田真規子、増田望穂、上林翔大、 \\ 森下 紀、種田健司、安堂有希子
}

\section{Laparoscopic resection of noncommunicating rudimentary uterine horn with functioning endometrium - report of two cases}

Masaya Hirose, Hiroshi Sato, Makiko Ikeda, Miho Masuda, Shota Kanbayashi, Hajime Morishita,

\author{
Kenji Oida, Yukiko Ando \\ Department of Obstetrics and Gynecology \\ Hyogo Prefectural Amagasaki General Medical Center, Japan
}

\begin{abstract}
A noncommunicating rudimentary uterine horn with functioning endometrium is a congenital Müllerian anomaly known to cause menorrhagia and abdominal pain. Here, we present two patients with a type $2 \mathrm{~b}$ uterine anomaly (American Society for Reproductive Medicine classification) and successful laparoscopic resection of the rudimentary horn in each.

Case 1. A 21-year-old female with a history of repeated clinic visits for menorrhagia was referred to our hospital due to findings showing an ovarian cystic tumor. CT and MRI results revealed an endometriotic cyst of the left ovary, left noncommunicating rudimentary uterine horn with functioning endometrium, and co-lateral renal agenesis. Laparoscopic resection of the rudimentary horn and left uterine adnexa was performed, after which the symptoms improved.

Case 2. A 41-year-old female underwent a laparoscopic cystectomy of the right ovary at 28 years of age and her uterus was suspected to be bicornuate at that time. However, that operation was apparently ineffective for alleviation of menorrhagia, and the patient was referred to our hospital due to its persistence as well as suspicion of endometriosis. MRI revealed a right noncommunicating rudimentary uterine horn with functioning endometrium. Laparoscopic resection of the rudimentary horn and right uterine adnexa improved the symptoms.
\end{abstract}

Key words: uterine anomaly, rudimentary uterine horn, laparoscopic surgery

\section{緒＼cjkstart言}

副角を有する単角子宮は先天性子宮形態異常の 中でも稀な疾患であり、機能性内膜を有し対側の 子宮角と交通のない非交通性副角子宮は月経困難 症や下腹部痛などの症状を呈す。特に若年者にお いては器質性月経困難症の原因として重要である1)。 また、非交通性副角子宮に子宮内膜症を併発する ことも多く ${ }^{2)}$ 、また、子宮付属器摘出後に月経困 難症が増悪した症例の報告もあり ${ }^{3)}$ 、適切な診断
治療が求められる。今回われわれは非交通性副角 子宮を伴う米国生殖医学会分類type $2 \mathrm{~b}$ の先天性 子宮形態異常と診断し、腹腔鏡下手術を行った 2 症例を経験したので報告する。なお、本論文の発 表に関して 2 症例とも患者本人から文書による同 意を得た。

\section{症 例 1}

21歳、未婚、未妊で、既往歴、家族歴に特記す べき事項は認めない。月経歴は初経が11歳で、周 
期は整調（28日周期）で初経後早期から月経困難 症を認めていた。月経困難症による救急受診のエ ピソードを反復していたが鎮痛剤の投与など対症 療法のみが行われ産婦人科診察など月経困難症の 原因検索は行われていなかった。

前日の夜間に左下腹部痛を認め前医に救急受診 したところ、骨盤内腫瘤を認め当科に紹介となっ た。経腹・経腟超音波断層検査では、子宮左側に $4 \mathrm{~cm}$ 大の腫瘤を認め、下腹部正中に $11 \mathrm{~cm}$ 大の囊 胞性腫瘤を認めた。MRIでは骨盤内左側に副角子 宮と思われる構造を認め子宮留血腫と考えられ た。下腹部正中には長径 $12 \mathrm{~cm}$ の囊胞性腫瘤を認 め、卵管留血腫あるいは卵巣内膜症性囊胞と考え られた (図 1 )。右卵巣は正常像として確認でき たが左卵巣は確認できなかった。子宮腟部は正中 にあり偏位は認めなかった。腹部CTでは、左腎 欠損と思われた（図 2 )。

腹腔鏡下手術を行うこととし、麻酔導入後に子 宮卵管造影検査を実施したところ、右子宮角と右 卵管は描出されたが左側は確認できなかった。術 中所見では、左副角には左円勒帯および左子宮付 属器が接続しており対側子宮角との間は疎な結合 織で接続していた。囊胞性腫箅は左卵巣由来で内 容液はチョコレート色で卵巣子宮内膜症性囊胞と 考えられた（図 3 )。副角㧍よび左卵管、左卵巣 腫瘍にS状結腸および直腸が高度に癒着しており 左子宮付属器の温存は困難と思われた。右子宮付 属器は正常で右子宮角と連続して存在した。以上 の所見から腹腔鏡下左副角子宮摘出術および左子 宮付属器切除術を施行した。骨盤漏斗勒带、子宮 角、および円勒帯と副角の切離は、ベッセルシー

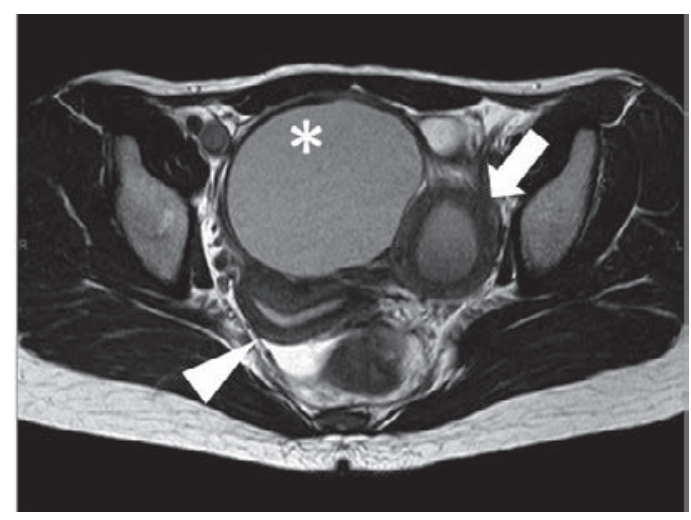

図 1 症例 1 の術前骨盤部MRI像 (横断面、T2強調画像)。 正中腹側に直径約 $8 \mathrm{~cm}$ のT2強調画像で低信号、T1強 調画像で高信号の左卵巣内膜症性囊胞あるいは卵管留 血腫と思われる襄胞性病変を認める $(*)$ 。その背側 に右単角子宮 (矢頭)、左側に左副角子宮 (矢印) を 認める。

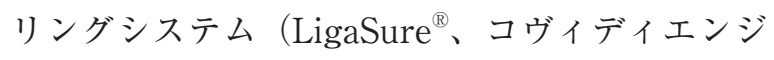
ヤパン）を用いた。癒着剥離は剥離鉗子あるいは 剪刃を用いた。子宮動脈と思われる血管は認めず、 対側子宮角との間は疎な結合織のみであった。手 術時間は子宮卵管造影検查の時間も含め 2 時間 47 分、術中出血量は $80 \mathrm{ml}$ であった。なお、子宮マ ニュピレーターは使用せず、摘出した副角および 子宮付属器は臍部の切開創を延長して回収した。

術後病理診断では内腔（機能性内膜）を有する 副角子宮でASRM分類 (American Society for Reproductive Medicine、米国生殖医学会) type $2 \mathrm{~b}$ 、 および左卵巣子宮内膜症性囊胞と診断した。術後、 月経困難症は改善したが、子宮内膜症の再発予防 を目的として術後 2 か月後から低用量エストロゲ ンープロゲスチン製片投与を継続中である。

\section{症 例 2}

41歳、未婚、未妊で、家族歴に特記事項はなか ったが、28歳時に卵巣子宮内膜症性囊胞に対して 腹腔鏡下右卵巣囊腫摘出術を受けており、高血圧 を合併していた。月経歴は初経が15歳で、月経周 期は整調（28日周期）であったが、高度の月経困 難症を認めていた。28歳時の術後にGnRHアナロ グ療法を数年間にわたり断続的に反復していたが 症状の改善は認めていなかった。

今回、月経困難症と子宮内膜症の治療を希望し 当科に紹介された。経腟超音波断層検査では右子

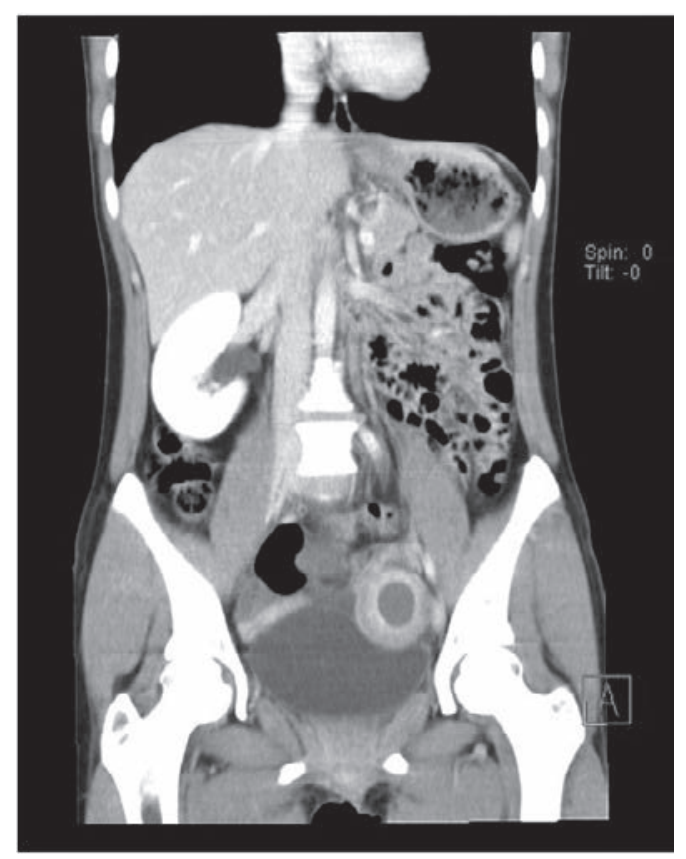

図2 症例1の術前腹部造影 C T 像 (前額断面)。左腎臓を 認めない。骨盤内左側に副角子宮を認める。 


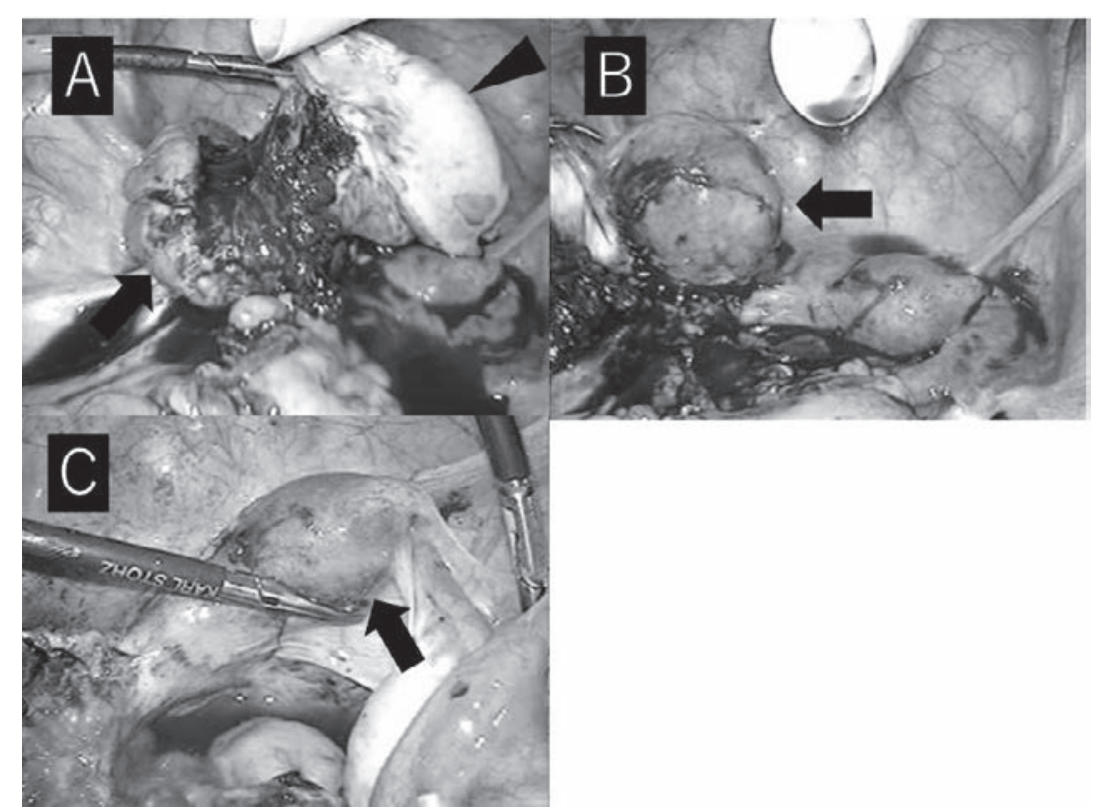

図3 症例 1 の術中所見。A、左卵巣囊胞（矢頭）を開放したところで卵管を認める（矢印）；B、 左子宮付属器を摘出したところで左副角子宮を認める（矢印）；、左副角を摘出したとこ ろで右単角子宮を認める（矢印）。

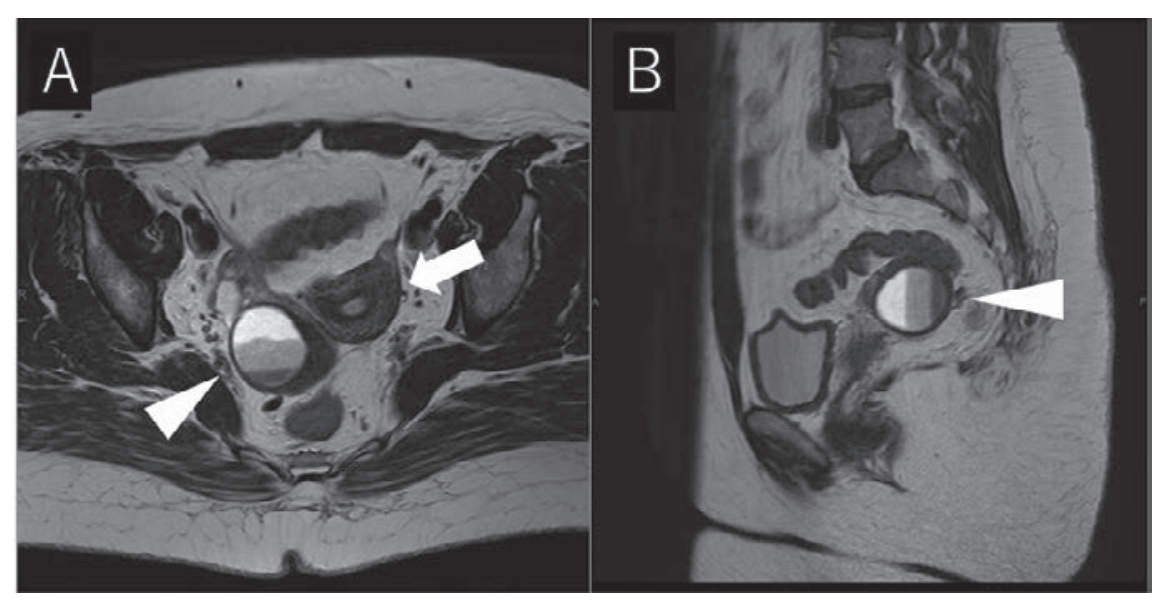

図4 症例2の術前骨盤部MRI像（横断面、T2強調画像）。A、横断面で内部に鏡面形成を伴う右副角子 宮（矢頭）と左単角子宮を認める（矢印）；B、矢状断面で右副角子宮の内部に鏡面形成を伴う液 体貯留を認める (矢印)。

宮付属器付近に直径約 $4 \mathrm{~cm}$ の比較的壁の厚い囊 胞性病変を認めた。子宮腟部は正中にあり偏位は 認めなかった。腹部超音波断層検查では両側腎臓 は正常に描出された。MRI検査で左単角子宮、右 副角子宮が疑われたため（図 4 ）、腹腔鏡下手術 を行うこととした。

術中所見では、左子宮角の対側に緊満し腫大し た右副角子宮を認め、副角子宮に連続して痕跡程 度の右子宮付属器を認め、右子宮付属器の温存は 不要と判断した（図 5 )。左子宮付属器は正常で 左子宮角に連続して存在した。子宮内膜症の所見 は認めなかった。以上の所見から右副角子宮摘出 術および右子宮付属器切除術を施行した。軽度の

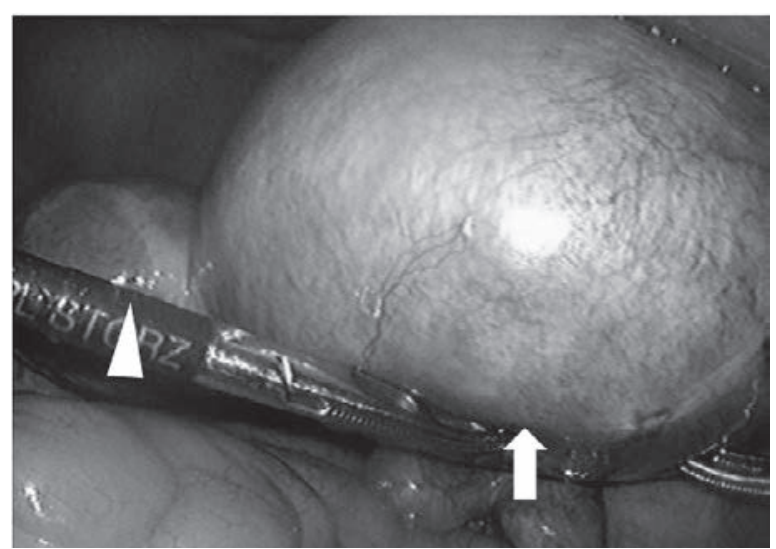

図 5 症例2の術中所見。右側に腫大した副角子宮を認め (矢印) 左 側に単角子宮を認める (矢頭)。 
癒着を認めたが、手術操作は症例1とほほ同様に 行った。子宮動脈と思われる血管は認めず、対側 子宮角との間は踈な結合織のみであった。尿管は 後腹膜のほぼ正常の位置に存在し副角とは近接し ていなかった。子宮マニュピレーターは使用せず、 摘出した副角および子宮付属器は臍部の切開創を 延長して回収した。手術時間は1時間55分、出血 量は少量であった。術後病理診断では機能性内膜 を有する副角子宮でASRM分類type $2 b$ と診断し た。術後、月経困難症は改善したが、子宮内膜肥 厚を認めたため周期的経口黄体ホルモン投与を継 続中である。

\section{考 察}

先天性子宮形態異常の分類としては、ASRM分 類 (American Society for Reproductive Medicine、米国生殖医学会 $)^{4)}$ とESHRE-ESGE分 類 (European Society of Human Reproduction and Embryology、欧州生殖医学会、European Society for Gynecological Endoscopy、欧州婦人 科内視鏡学会 $)^{5)}$ が知られている。本症例は、 ASRM分類ではtype2b、ESHRE-ESGE分類では class U4a となる。本論文では、ASRM分類を用 いた。

胎生期の左右のミュラー管の癒合不全や形成不 全により様々な形態の先天性子宮形態異常が起こ ることが知られている。その頻度は、かつては 1 \%未満とされていたが、MRIなどの新たな診断法 の導入により $3 \sim 4 \%$ と比較的高頻度に認められ る考えられるようになってきている ${ }^{6)}$ 。単角子宮 （ASRM分類 type2/Unicornuate）の頻度は先天 性子宮形態異常の $2.4 \sim 10 \%$ 、全女性の $0.1 \%^{7)}$ で type 2c（内腔のない副角）が最も多く、次に多 いのが2b（交通のない副角）で20～ $25 \%$ とされ、 $2 \mathrm{a}$ (交通のある副角) は少ない。

非交通性副角子宮では子宮内膜症を合併してい ることが $21 \% \sim 33 \%^{2)}$ と多く、機能性内膜からの 月経血が経卵管的に腹腔内に流入することが子宮 内膜症発生に関与している可能性がある。一方、 月経困難症は併存する子宮内膜症によることも考 えられるが、初経後比較的早期から月経困難症が 出現することが多いことから、月経血の子宮腔充 満と腹腔内への流入が月経困難症の本来の原因と 思われる。症例 2 では、卵巣子宮内膜症の手術歴 があったが、今回の手術では子宮内膜症の所見は 認めなかった。手術歴のある側の子宮付属器は委 縮しており、既往手術により卵管が閉塞し月経血
の腹腔内への流入が消失していた可能性が高くこ れが子宮内膜症の発生を抑制していたのかもしれ ない。また、子宮付属器摘出により月経血が子宮 腔に密封されたために月経痛が増悪した症例3,8) や、付属器摘出後の産裖期に血液貯留を来したし た症例 $)^{9}$ も報告されており、既往の付属器摘出術 が症例 2 の月経困難症の継続、悪化に関係してい たのではないかと推察された。

治療は月経困難症の改善、子宮内膜症の予防、 副角子宮側卵管妊娠や副角妊娠の予防目的で副角 切除㧍よび副角側卵管切除が勧められる の手術手技については、対側子宮角との結合状況、 尿管の有無 - 走行状況、併発する子宮内膜症の重 症度により難易度が異なるとされる ${ }^{10)}$ 。単角子宮 では片側のウォルフ管の形成不全があり、病的な 子宮角の側に腎無形成をはじめとする腎尿路系の 奇形を伴うことが多く、頻度は $38 \%$ と報告されて いる ${ }^{11)}$ 。その場合は尿管に対する配慮は不要であ るが、尿管が存在する場合は走行が偏位している 場合があり注意が必要である。今回の 2 症例では 行わなかったが、腎欠損がなく高度の子宮内膜症 がある場合は、一般的な子宮摘出に打ける尿管損 傷抑止のための尿管ステント併用 ${ }^{12)}$ や、一時的 な症状緩和 ${ }^{1)}$ と子宮内膜症の改善を目的とする術 前のGnRHアゴニスト投与を考虑しても良いかも しれない。黄体ホルモン製剤であるジェノゲスト の術前投与はGnRHアゴニストに比し、卵巣内膜 症性囊胞核出を容易にし、核出による卵巣機能に 対する影響も少ないとの報告 ${ }^{13)}$ があり、今後検 討するべき課題であるが、現時点では、副角子宮 の待機中における黄体ホルモン製郕使用に関する 報告は見当たらない。

子宮動脈の走行については副角子宮側の子宮動 脈は単角子宮頸部に流入しており、子宮動脈本幹 を処理することなく副角子宮を切除できることが 多いとされるが子宮動脈が副角へ流入する場合も あり、尿管の走行とともに副角の側方の処理時に 確認が必要である ${ }^{14)}$ 。一方、対側の子宮角との結 合が強い場合は、その切離に際して、対側子宮角 の損傷を最小限にするために副角を楔状に切離す る方法が提唱されており一考に值する ${ }^{15)}$ 。術前あ るいは術中に、MRI、子宮卵管造影検查、子宮鏡 検査などによりできるだけ正確に状態を把握し、 術中に、尿管、子宮動脈、対側子宮角、子宮内膜 症による癒着などに配慮することにより十分安全 に腹腔鏡下副角子宮摘出術を行うことができると 考えられるが、術中の所見で副角と対側子宮角の 
関係を把握し、必要があればその時点で、子宮鏡 あるいは子宮卵管造影検査を行う、といった対応 で検查の省略ができる可能性はある。症例 1 では 患者の苦痛を避けるために子宮卵管造影検査を麻 酔導入後に実施したが術中に副角と対側子宮角と の結合は希薄であることが判明したためその必要 度は低かったと思われた。

長期的な観察においては子宮頸部組織の遺残な ど他の異常が併存している可能性 ${ }^{16)}$ と妊娠分婏 に対する配慮が必要である。副角子宮摘出後の妊 娠については、現時点では腹腔鏡下副角摘出術の 影響は認めないとのSawadaら ${ }^{17)}$ の報告があり、 一般的な単角子宮での妊娠分婏の成績 ${ }^{18)}$ と同様 と考えられるが温存した単角子宮の損傷・修復の 度合いによる相違までは明らかではない。しかし ながら、副角子宮摘出は予後不良な副角妊娠を防 止できるメリットは大きいものと考えられる。

「副角」「腹腔鏡」を検索ワードにした医学中央 雑誌による文献検索では、非妊娠時の腹腔鏡によ る非交通性副角子宮摘出術の報告は 14 編認められ たが複数症例を報告しているのは大塚ら ${ }^{19)}$ の報 告のみであり、本報告が2編目となる。このように、 非交通性副角子宮は非常にまれであり、同一術者 が複数症例の手術を担当することはさらにまれな ことといえる。国外に目を向ければ、PubMedで の「rudimentary」「laparoscopy / laparoscopic」 を検索ワードにした文献検索による英文雑誌に掲 載された腹腔鏡による非交通性副角子宮摘出術に 関する報告は28編認められた。この中で、Fedele $ら^{20)}$ は10例の腹腔鏡下非交通性副角子宮摘出術 を報告しており傑出している。このように腹腔鏡 下副角摘出術の報告は多く、希少性はさほど高く ないと思われれるが、症例の背景、実際の手術手 技は多様性に富み、症例の報告による臨床経験の 蓄積は今後も有用と思われる。今回の 2 症例では 若年女性の月経困難症において先天性子宮形態異 常をはじめとする器質性月経困難症を念頭に置く ことの重要性と、卵巣子宮内膜症性囊胞の治療に あたっては本疾患を念頭に置くことの必要性が再 認識された。また、症例 2 では、過去の子宮付属 器摘出後に月経困難症の増悪がみられており、非 交通性副角子宮では月経血の腹腔内への流入が月 経痛の原因であるとともに、子宮腔の月経血充満 を緩和するドレナージ効果も果たしており、卵管 閉塞あるいは䟔失によりその効果が失われると月 経困難症が増悪するのではないかと推察された。

\section{結 語}

腹腔鏡下非交通性副角子宮摘出術は低侵襲で安 全に実施できる治療法である。月経困難症を呈す る症例では先天性子宮形態異常が原因となる場合 もあることを考慮しつつ対応し、正確な診断、適 切な治療が肝要と考えられた。

本論文の要旨は第 59 回日本産婦人科内視鏡学会 学術講演会において発表した。

すべての著者は開示すべき利益相反はない。

\section{参考文献}

1) American College of Obstetrics and Gynecology.: Management of Acute Obstructive Uterovaginal Anomalies: ACOG Committee Opinion, Number779. 2019;133: e363-371.

2 ) Olive DL, Henderson DY: Endometriosis and Müllerian anomaries. Obstet gynecol 1987; 69: 412-415.

3) Tanaka Y, et al.: Case of iatrogenic dysmenorrhea in non-communicating rudimentary uterine horn and its laparoscopic resection. J Obstet Gynaecol Res 2005: 31: 242-246.

4) The American Fertility and Society: The American Fertility Society classification of adnexal adhesion, distal tubal occlusion, tubal occlusion secondary to tubal ligation, tubal pregnancies, Müllerian anomalies and intrauterine adhesions. Fertil Steril 1988; 49: 944-955.

5 ) Grimbizis GF, et al.: The ESHRE-ESGE consensus on the classification of female genital tract congenital anomalies. Gynecol Surg 2013; 10: 199-212.

6 ) Acien P: Incidence of Müllerian defects in fertile and infertile women. Hum Reprod 1997; 12: 1372-1376.

7 ) Grimbizis GF, et al: Clinical implications of uterine malformation and hysteroscopic treatment results. Hum Reprod Update 2001; 7: 161-174.

8 ）世良亜紗子、ほか：付属器摘出後より副角に 子宮留血腫を発症した1例. 東京産科婦人科 学会会誌 $2015 ； 64 ： 390-393$. 
9 ) 宮木康成、ほか：産裖期に診断され腹腔鏡下 非交通性副角子宮摘出術を施行した1例。日 産婦内視鏡学誌 $2013 ; 29: 98-102$.

10) Shirk GJ, Johns A, Redwine DB : Complications of laparoscopic surgery: how to avoid them and how to repair them. J Minim Invasive Gynecol 2006; 13:352-359.

11) Heinonen PK : Unicornuate uterus and rudimentary horn. Fertil Steril 1997: 68: 224230.

12) Merritt AJ, et al:: Prophylactic pre-operative bilateral ureteric catheters for major gynecological surgery. Arch Gynecol Obstet 2013; 288: 1061-1066.

13）土屋雄彦、ほか：腹腔鏡下卵巣チョコレート 囊胞摘出術における術前薬物療法の検討. 日 産婦内視鏡学誌 $2017 ; 33: 176-182$.

14) Giatras K, Licciardi FL, Grifo JA: Laparoscopic resection of a noncommunicating rudimentary uterine horn. J Am Assoc Gynecol Laparosc. 1997; 4: 491-493.

15) Akdemir A, et al.: Corning-type laparoscopic resection of a cavitated non-communicating rudimentary horn under hysteroscopic assistance. J Obstet gynaecol Res 2014; 40: 1950-1954.

16) Nakhal RS, et al.: Remnant functioning cervical tissue after laparoscopic removal of cavitated noncommunicating rudimentary uterine horn. J Min Inv Gynecol 2012; 19: 768-771.

17) Sawada M, et al.: Obstetric outcome in patients with a unicornuate uterus after laparoscopic resection of a rudimentary horn. J Obstet Gynaecol Res 2018; 44: 10801086.

18) Raga F, et al.: Reproductive impact of congenital Müllerian anomalies. Hum Reprod 1997; 12: 2277-2281.

19）大塚博文、ほか：腹腔鏡下に片側子宮を摘出 した子宮奇形の 2 症例. 日産婦内視鏡学誌 $2018 ; 34: 296-300$.

20) Fedele L, et al.: laparoscopic removal of the cavitated noncommunicating rudimentary uterine horn: surgical aspect in 10 cases. Fertil Steril 2005: 83: 432-436. 